\title{
醬油䤙造微生物学の進歩 $(1)$
}

踾油は味噌とともに中国から伝えられ，わが国で独自の発達をなしとげた発醂食品である。穀物タンパク質を微生 物酳素のカをかりて全く異筫の食品に転換する技術は, 昨今欧米先進国からもバイオテクノロジーの典型的な例とし て注目されている。

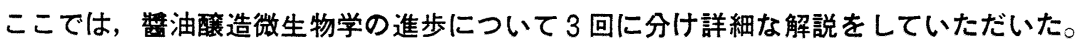

\section{水 沼 武 二}

仏教の伝来後，大豆や麦などの穀類を原料とした醬油 の原型である穀醬（こくびしお）が中国から伝えられ， 次第にわが国独自の醬油へと発展してきた。しかし明治 初期までは, 醬油醸造に関与する微生物の働きについて の詳細はほとんど不明であった。明治後期になって, 醬 油微生物の分類学的研究が開始された。1950 年ごろ以 降、その生理・生化学・酵素・遗伝・育種などに関する 研究が, 一般微生物学の急速な進歩に伴って著しく進展 した。

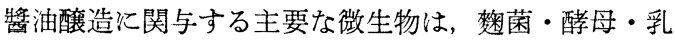
酸菌であり, その活動のいかんは醬油の品質・歩留りに 多大な影響を及ぼす。最近は, 消費者之生産者の双方に とり, 品質への関心が高まり, 同時低塩化・淡色化・ 高級化などの多様化傾向が強い。加えて, 生産者には二 ストダウンという必然的な要請もある。これら係わる すべてを網羅することは, 浅学の筆者には不可能である ので, 実際の醬油醸造に直接関倸し, しかも最近約 10 年間の微生物についての研究を中心に述べる。1971 年 以前の文献は, 成書 ${ }^{1} 飞$ 載っているものも参照されたい。 なお総説のある研究については, できるだけ個々の文献 の記載を控えたことを付記する。

\section{1. 徆油药菌に関する研究}

滰油棅菌としては, 大豆・小麦のタンパク質やデンプ ンなどの高分子成分を加水分解する酵素の生産能の高い ものが適している。醬油醸造の第 1 段階では, 蒸募変性 した大豆と, $\alpha$ 化した割砕炒り小麦の混合物に, 純粋培

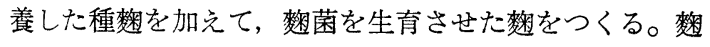
は，細菌が生産したプロテアーゼ・ペプチダーゼ・グル
タミナーゼ・アミラーゼをはじめ, 多種類の酵素を多量 含有している。なかでも醬油醇造で最も重要な役割を果 す麴菌酵素は, 原料中のタンパク質を分解して, 呈味の 主体をなすフミノ酸などを生成するプロテアーゼ系酵素 である。酵素生産能の高い粷菌株の使用により, 醬油の 歩留りが多くなり, また菌株により醬油の香味などの品

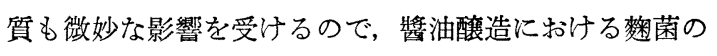
むつ意義は極めて大きい。

\section{1 醬油麴菌の多様性}

古く 1876 年に, 東京神田の甘酒剓から Ahlburg によ り分離されたカビは, Aspergillus oryzae (Ahlburg) Cohn と命名された。高橋 (1909) は, 本邦の伝統的醸造 用の種麴から分離したカビは, A. oryzae (Ahlburg) Cohn とその変種であるとし，これを初めて䊝菌とよん だ。後に坂口ら ${ }^{21}$ は, 分生子に小突起をもつ醬油用麴菌 A. sojae Sakaguchi et Yamada の種を新設して, 麴菌 A. oryzae group の分類法を提示した。この浪か藥菌の 分類については, 形態・生理面から多数の研究がある。

最近の村上 ${ }^{3,4)}$ の分類学的研究によると, わが国の伝統 的な醸造で主役を果している黄粷菌には，A. oryzae お よびその変種, A. sojae, A.tamarii の 3 分類種がある。 A. oryzae は清酒・味噌・醬油用などに広く用いられ, A. sojae は醬油用に限定されている。A.tamarii の使用

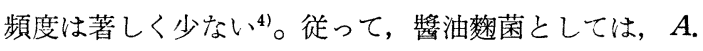
oryzae とA. sojae が使用されているといえる。

村上 ${ }^{5,61}$ は, カビの 20 種類の性質について各菌株の固 有な方向量を計算し， 5 次元空間にプロットして類似性 を比較する多变量解析によって, 黄緑アスペルギルスを 黄棅菌群（オリゼー群）と野生菌群（フラブス群）とに 
大別した。この新分類法によると, 醸造に用いられる A. oryzae と A.sojae は, アフラトキシンを全くつくら ない黄麴菌群に属する。一方, A. flavus や A. parasiticus は野生菌群に入り, アフラトキシンを生産する菌株 を包含している。

従来, Raper-Fennel (1965) の分類法では, A. sojae は A. parasiticus の中に包括されていた。最近, 村上7,8) は，分類キィーを一部改定して，第 1 表のように，長期 間培養した成熟分生子頭の色と, アニスアルデヒド培地 での分生子のピンク着色の有無によって, A. parasiticus とA.sojae とをより明確に分類できることを示した。 また分生子に小突起をすつ野生菌 A. parasiticus は, 亜 鉛含有ツァペック培地で培養すると, $410 \mathrm{~nm}$ に極大吸 収をるつ黄色色素をつくり, 麴菌 A. sojae はこの色素を 生産しない9。これらのことを考慮して, アィリカ菌株 保存機関 (ATCC) でも, 1982 年以降, A. sajae はA. parasiticus とは異なる 分類種 Aspergillus sojae Sakaguchi et Yamada ex Murakami として記載することに なった。

A. oryzae とA sojae とは形態的特徵も異なり, その

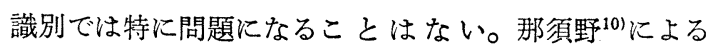
之, 憗䊝の粗酵素抽出液中のアルカリプロテアーゼ・酸

第 1 表 黄緑小突起分生子株の分類に関する RaperFennell (1965) と村上 (1982)の Key の違い 7,8)

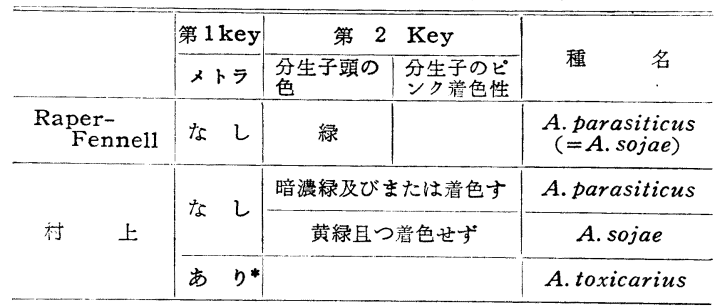

*大小多少に関係ない
性プロテアーゼ・セルラーゼ・ペクチナーゼの電気泳動 パターンは, A oryzae と A. soiae 間で種特異的で方る ので, 両菌種の識別法としても利用できる。

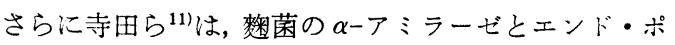
リガラクチュロナーゼ (Endo-PG) の生産能を指標とす る簡易分別法を提示した。A. oryzae とA. sojae が生産し, 醸造に関連深い12 種の酵素について, 両菌種間に晾门 るその生産能を比較したところ， $\alpha$ アミラーゼと Endo-


は A. oryzae が高く, 逆に Endo-PG は A. sojae が極湍 に高かった。従って, これらの酵素の生産能比率は, 両 菌種間で著しい差があることが推計学的に認められた。

この簡易分別法と形態的特徵によって, 分類学的に A. oryzae か A. sojae に属することが確認された多くの 醬油用楊菌株を供試して, 林ら ${ }^{12)}$ は両分類種間の醬油醸 造特性上の差について系統的に検討した。その結果, 第 2,3 表のように, A. sojae 株は, A. oryzae 株と比較して

第 2 表 㮃菌分類種による製釉中炭水化物消費の差: ${ }^{12)}$

\begin{tabular}{|c|c|c|c|c|c|c|}
\hline & & & $\begin{array}{l}\text { 槒の乾物 } \\
\text { 重量 }\end{array}$ & $\begin{array}{l}\text { 效の転化 } \\
\text { 糖 }\end{array}$ & $\begin{array}{l}\text { 笏より生成 } \\
\text { するグルコ } \\
\text { ース }\end{array}$ & 数 $\mathrm{pH}$ \\
\hline 試 & $\begin{array}{l}\text { A. sojae } \\
(n=11)\end{array}$ & $\begin{array}{l}\bar{x} \\
\sigma\end{array}$ & $\begin{array}{c}789 \\
(19)\end{array}$ & $\begin{array}{r}350 \\
(34)\end{array}$ & $\begin{array}{r}248 \\
(23)\end{array}$ & $\begin{array}{c}7.03 \\
(0.39)\end{array}$ \\
\hline \multirow{2}{*}{$\begin{array}{l}\text { 験 } \\
\text { I }\end{array}$} & $\begin{array}{c}\text { A. oryzae } \\
(n=11)\end{array}$ & $\begin{array}{l}\bar{x} \\
\sigma\end{array}$ & $\begin{array}{l}748 \\
(19)\end{array}$ & $\begin{array}{l}256 \\
(16)\end{array}$ & $\begin{array}{l}150 \\
(15)\end{array}$ & $\begin{array}{c}6.41 \\
(0.20)\end{array}$ \\
\hline & \multicolumn{2}{|c|}{ 有意差检定 ${ }^{a)}$} & $\mathrm{S}>\mathrm{O}^{* * *}$ & $\mathrm{~S}>\mathrm{O}^{* * *}$ & $\mathrm{~S}>\mathrm{O}^{* * *}$ & $\mathrm{~S}>\mathrm{O}^{* * *}$ \\
\hline 試 & $\begin{array}{l}\text { A. sojae } \\
(n=12)\end{array}$ & $\begin{array}{l}\bar{x} \\
\sigma\end{array}$ & $\begin{array}{l}795 \\
(8)\end{array}$ & $\begin{array}{r}357 \\
(16)\end{array}$ & $\begin{array}{r}253 \\
(13)\end{array}$ & $\begin{array}{c}6.71 \\
(0.17)\end{array}$ \\
\hline 験 & $\begin{array}{c}\text { A. oryzae } \\
(n=12)\end{array}$ & $\begin{array}{l}\bar{x} \\
\sigma\end{array}$ & $\begin{array}{c}754 \\
(14)\end{array}$ & $\begin{array}{r}264 \\
(22)\end{array}$ & $\begin{array}{l}156 \\
(20)\end{array}$ & $\begin{array}{l}6.33 \\
(0.14)\end{array}$ \\
\hline & 有意差检 & & $\mathrm{S}>\mathrm{O}^{* * *}$ & $\mathrm{~S}>\mathrm{O}^{* * *}$ & $\mathrm{~S}>\mathrm{O}^{* * *}$ & $\mathrm{~S}>\mathrm{O}^{* * *}$ \\
\hline
\end{tabular}
( $\mathrm{g} /$ 原料 $\mathrm{kg}$ )

a) $\mathrm{S}:$ A. sojae, $\mathrm{O}:$ : oryzae - $(\mathrm{S}=\mathrm{O})$ : 有意差なし, *,*****( $\mathrm{S}>\mathrm{O}$ または $\mathrm{S}<\mathrm{O})$ それ ぞれ $5 \%, 1 \%, 0.1 \%$ 有意水染での大小阅係走示

第 3 表 䴹菌分類種による銺油䊝酵素力の差 ${ }^{12)}$

\begin{tabular}{|c|c|c|c|c|c|c|c|c|c|c|c|}
\hline & & & \multicolumn{2}{|c|}{ プロテアーゼ (PU/g) } & \multicolumn{2}{|c|}{ ペプチダーセ（u/g) } & \multirow{2}{*}{$\begin{array}{l}\alpha-ア ミ ラ- \\
\Downarrow \\
(\mathrm{ku} / \mathrm{g})\end{array}$} & \multicolumn{2}{|c|}{ ベクチナーゼ(u/g) } & \multirow{2}{*}{$\begin{array}{c}\text { グルミナ } \\
\text { 一ゼ } \\
(\mathrm{u} / \mathrm{g})\end{array}$} & \multirow{2}{*}{ 麭菌体量e) } \\
\hline & & & $\mathrm{pH} 7$ & $\mathrm{pH} 3$ & $A(C P a)$ & $\mathrm{LAPb}$ & & PGc) & $P(d)$ & & \\
\hline 試 & $\begin{array}{l}\text { A. sojae } \\
(n=11)\end{array}$ & $\begin{array}{l}\bar{x} \\
\sigma\end{array}$ & $\begin{array}{c}275 \\
(110)\end{array}$ & $\begin{array}{c}39 \\
(17)\end{array}$ & $\begin{array}{c}0.63 \\
(0.32)\end{array}$ & $\begin{array}{c}1.11 \\
(0.18)\end{array}$ & $\begin{array}{l}22.1 \\
(8.7)\end{array}$ & $\begin{array}{c}50.4 \\
(26.6)\end{array}$ & $\begin{array}{c}49.2 \\
(22.3)\end{array}$ & $\begin{array}{c}48.4 \\
(12.2)\end{array}$ & $\begin{array}{c}4.69 \\
(0.85)\end{array}$ \\
\hline \multirow{2}{*}{$\begin{array}{l}\text { 験 } \\
\text { I }\end{array}$} & $\begin{array}{c}\text { A. oryzae } \\
(n=11)\end{array}$ & $\bar{x}$ & $\begin{array}{c}218 \\
(379)\end{array}$ & $\begin{array}{c}98 \\
(15)\end{array}$ & $\begin{array}{c}2.29 \\
(0.79)\end{array}$ & $\begin{array}{c}1.11 \\
(0.23)\end{array}$ & $\begin{array}{l}195 \\
(87)\end{array}$ & $\begin{array}{l}22.0 \\
(6.6)\end{array}$ & $\begin{array}{c}49.2 \\
(44.0)\end{array}$ & $\begin{array}{c}35.7 \\
(12.4)\end{array}$ & $\begin{array}{l}5.27 \\
(1.07)\end{array}$ \\
\hline & \multicolumn{2}{|c|}{ 有意差検定f) } & $\overline{\mathrm{S}=\mathrm{O}}$ & $\mathrm{S}^{* * *}<\mathrm{O}$ & $\mathrm{S}<\mathrm{O}$ & $\overrightarrow{\mathrm{s}=\mathrm{O}}$ & $\stackrel{* * *}{\mathrm{~S}<\mathrm{O}}$ & $\mathrm{S}>\mathrm{**} \mathrm{O}$ & $\overline{\mathrm{S}=0}$ & $s \stackrel{*}{ }>0$ & $\overline{\mathrm{S}=\mathrm{O}}$ \\
\hline 試 & $\begin{array}{l}\text { A. sojae } \\
(n=12)\end{array}$ & $\begin{array}{l}\bar{x} \\
\sigma\end{array}$ & $\begin{array}{l}271 \\
(95)\end{array}$ & $\begin{array}{c}43 \\
(13) \\
\end{array}$ & $\begin{array}{c}0.80 \\
(0.18)\end{array}$ & $\begin{array}{c}1.20 \\
(0.39)\end{array}$ & $\begin{array}{l}18.7 \\
(6.8)\end{array}$ & $\begin{array}{c}53.2 \\
(18.1)\end{array}$ & $\begin{array}{c}60.0 \\
(40.1)\end{array}$ & $\begin{array}{c}49.5 \\
(19.2)\end{array}$ & $\begin{array}{c}5.00 \\
(1.12)\end{array}$ \\
\hline \multirow{2}{*}{$\begin{array}{l}\text { 験 } \\
\text { II }\end{array}$} & $\begin{array}{c}\text { A. oryzae } \\
(n=12)\end{array}$ & $\bar{x}$ & $\begin{array}{l}208 \\
(48)\end{array}$ & $\begin{array}{l}104 \\
(18)\end{array}$ & $\begin{array}{c}2.70 \\
(0.58)\end{array}$ & $\begin{array}{c}0.98 \\
(0.25)\end{array}$ & $\begin{array}{l}244 \\
(87)\end{array}$ & $\begin{array}{c}20.5 \\
(12.4)\end{array}$ & $\begin{array}{c}50.9 \\
(12.5)\end{array}$ & $\begin{array}{l}31.9 \\
(7.8)\end{array}$ & $\begin{array}{l}5.56 \\
(1.54)\end{array}$ \\
\hline & \multicolumn{2}{|c|}{ 有意差検定f } & $\overline{\mathrm{S}=\mathrm{O}}$ & $\mathrm{S}<\mathrm{O}$ & $\mathrm{S}^{* * *}<\mathrm{O}$ & $\overline{\mathrm{S}=\mathrm{O}}$ & $\mathrm{S}^{* * *}<\mathrm{O}$ & $\mathrm{S}>\mathrm{O}$ & $\overline{\mathrm{S}=\mathrm{O}}$ & $\mathrm{S}^{* *} \mathrm{O}$ & $\overline{\mathrm{S}}=\mathrm{O}$ \\
\hline
\end{tabular}

a) 酸性カルボキシペプチダーゼ. b) ロイシンアミノペプチターゼ, c) エンド・ポりガラクチュロナーゼ, d)ペクチンリアービ,

e) キチン $\mathrm{g} /$ 原料 $\mathrm{kg}$, f) 第 2 表参熙 
次の特徴定有することが判明した。すなかち, (1)出㮦の $\mathrm{pH}$ が高く、クエン酸のような有機酸が少ない。2製数 中の炭水化物消費量が少ない。(3)楿の $a$-アミラーゼ・ 酸性プロテアーゼ・酸性カルボキシペプチダーゼ活性が 低く，エンド・ポリガラクチュロナーゼ活性が高い。(4) 諸味粘度が低い。(5)生醬油中に残存する各種酵素量が少 なく，火入れ垽が少ない。(6)生醬油中の還元糖・乳酸・ アンモニアの含量が多く, pH が低い。もらうん, これ は推計学的結論であるので, A. sojae 株でも菌株注よっ て注, A oryzae に近い醸造特性を有するものがある。

醸造用栭菌 A. oryzae, A. sojae でアフラトキシンを つくるものは，現在まで全く見出されていない(5,6)。しか し，アフラトキシンの検出には薄層クロマトグラム上の 蛍光活性と Rf 值が多用されるために, 栾菌もアフラト キシンをつくるという間違った報告がされることがあっ た。この問題を佐々木ら ${ }^{131}$ は詳細に検討して, 樬菌培養 物中に蛍光活性と Rf 值がアフラトキシンと極めて紛ら わしい物質を多数認めた。その 1 つはピラジン環化合物 で，他はイソクマリン環化合物であることを証明した。 さらに, これらの物質は, 動物実験の結果, 毒性は弱く, 実際の生活面では全く問題てならないと述べている。

A. flavus や A. parasiticus の中のアフラトキシン生産 菌株は，わが国では年間平均気温 $16^{\circ} \mathrm{C}$ 以上の四国や九 州の南部以南の土中にしか検出されていない(14)。長い年 月を通じて選択され使用されてきた，わが国の醸造用麴 菌が全くアフラトキシンをつくらないことは，先人たち の経験に基づく知恵の遺産であると考えられる。

\section{2 麴菌增殖および各種酵素の生産・機能}

1.2.1 落菌增殖菌醬油醇造においてその機 能を発揮するには, まず原料上で増殖し, 各種類の酵素 を生産することが必要である。よく知られているよう に, 㷊菌の増殖には温度・湿度・水分・ $\mathrm{pH}$ ・酸素など が影響する。奈良原 ${ }^{15}$ によると, 水分摂取の難易さの指 標である水分活性 $\left(a_{W}\right)$ が $0.980 \sim 0.990$ のとき, $A$. oryzae は最大增殖速度を示す。この最適 $a_{W}$ は培養温 度の影響をほとんど受けない。最適 $a_{W}$ における增殖 速度は $30^{\circ} \mathrm{C}, 35^{\circ} \mathrm{C}$ で最大となり, $25^{\circ} \mathrm{C}$ における增殖速 度の $1.2 \sim 1.6$ 倍である。

一方, 加藤ら ${ }^{16,177}$ は, モデル的に培養した䴯中の麴菌 菌体量と各種酸造指標との相関を求めた。第 1 図のよう に, 楼菌菌体量と, 槒中のプロテアーゼ・アミラーゼ活 性や棦消化液中の総窒素溶解利用率 (TNUR), グルタ ミン酸/総窒素 $(\mathrm{Glu} / \mathrm{TN})$ との間汇高い正の相関関係 が認められた。この結果は重要な意味をもっていて, 麴 中の菌体量が多いほど, つまり原料の麴化の程度が進む ほど，各種の醸造指標は良好になることを示唆する。

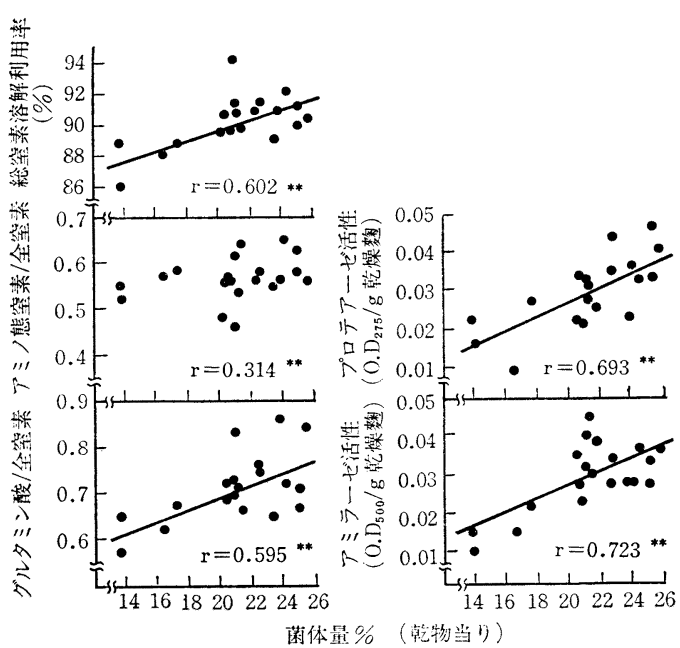

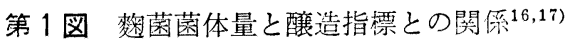

**: $1 \%$ の危除率で有意

醬油桷中の麭菌菌体量は, 細胞壁の構成成分であるグ ルコサミンの含量を指標とする方法が案出された。小崎 $5^{18)}$, 加藤ら ${ }^{16,17)}$, 中台 ${ }^{19}$ は, それぞれ 14〜18\% (乾物 当り), $12.8 \%$ (乾物当り), $12 \%$ （湿物当り）と報告し ている。

高草ら ${ }^{201}$ は, A. oryzae の分生子が発芽して, 菌系が $200 \sim 300 \mu$ 伸長するとプロテアーゼの生成が始まり, 以 後は培養温度により力価の強弱があることを認めた。さ

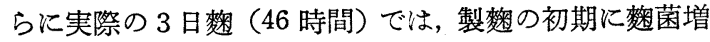
殖の適温にして, 早く菌系を $200 \sim 300 \mu$ に生育させ, その後はプロテアーゼの生産至適温度の $23^{\circ} \mathrm{C}$ に下げる と, 酵素力価の高い䴹がえられるとした。

また楝菌は, 培地の栄養分がなくなったり，それを利 用できない飢餓条件下では，すでに菌体内に蓄積されて いるタンパク質・糖質・核酸などを自家呼吸基質として 分解・利用する ${ }^{21}$ 。

1.2.2 プロテアーゼ 醬油原料中のタンパク質を 分解して, 醬油の呈味の基本成分であるアミノ酸などの 生成に関与するのは棅菌プロテアーゼ系である。その中 で, タンパク質をベプチドに分解する醭素がプロテアー ゼで, 生成したペプチドをさらに分解してアミノ酸にす るのがペプチダーゼである。

すでに好井 ${ }^{22}$ は，醬油䁔造におけるプロテアーゼの活 用方策について, 多数の研究結果を総括して述べてい る。また一島 ${ }^{23}$ は, 釈菌酵素の醸造に和ける役割, 生化 学的側面から, 森原 ${ }^{24)}$ は, プロテアーゼの種類と基質特 異性について詳細に総説している。最近では, 井ロら ${ }^{25)}$ による醬油醸造と微生物とくに䊝菌酵素に関する優れた 総説がある。そのほか，釈菌プロテアーゼに関する研究 
第 4 表 枍菌のプロテアーゼ組成 ${ }^{23)}$

\begin{tabular}{|c|c|c|c|c|}
\hline \multicolumn{2}{|c|}{ プロテフーゼ } & 分子 量 & 醖素単位/g 敕 & $\begin{array}{l}\text { 䣲 素 量 } \\
(\mu \mathrm{g}) / \mathrm{g} \text { 棃 }\end{array}$ \\
\hline 酸 & 性 I & 39,000 & $44.1^{*}$ & 617 \\
\hline 酸 & 性 II & 100,000 & $10.0^{*}$ & - \\
\hline 酸 & 性 III & 31,000 & 4. $6^{*}$ & - \\
\hline 中 & 性 I & 41,000 & $80.0^{* *}$ & 131 \\
\hline 中 & 性 II & 19. 300 & $8.7^{* *}$ & 152 \\
\hline & ルカリ & 32,000 & $55.4^{* *}$ & - \\
\hline & カ & 23,000 & $929 * *$ & 418 \\
\hline
\end{tabular}

* カゼイン ( $\mathrm{pH} 3.0)$ 分解活性, ** カゼイン ( $\mathrm{pH} 7.0)$ 分解活性 （注）セファデックス G-100により分離

第 5 表 麴菌のロイシンアミノペプチダーゼの組成 ${ }^{26)}$

\begin{tabular}{|c|c|c|c|c|c|}
\hline $\begin{array}{l}\text { ロイシンフ } \\
乏 \text { ミペブチ } \\
\text { ダーゼ }\end{array}$ & 分子量 & $\begin{array}{l}\text { Leu-Gly- } \\
\text { Gly } \\
\text { 単位/g }\end{array}$ & $\begin{array}{c}\text { Leu-2- } \\
\text { NNap } \\
\text { 単位/g 数 }\end{array}$ & $\begin{array}{l}\text { Leu-p- } \\
\text { NA } \\
\text { 単位 } / g \text { 剓 }\end{array}$ & 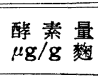 \\
\hline I & 26,500 & 0.102 & $0.68 \mathrm{v}$ & 2. 420 & 319 \\
\hline II & 61,000 & 0.246 & .0342 & 0.163 & 54 \\
\hline III & 55,000 & 0.145 & l（而が主体） & 0.047 & 301 \\
\hline IV & 130,000 & 0.152 & 0 & 0 & 200 \\
\hline $\mathrm{V}$ & 100,000 & 0.111 & 0.003 & - & - \\
\hline $\mathrm{VI}$ & 39,000 & 0.009 & 0.071 & - & - \\
\hline VII & 170,000 & 0.034 & 0.001 & 0.002 & - \\
\hline $\begin{array}{l}\text { フリルアミ } \\
\text { ダーぜ }\end{array}$ & 130,000 & 0 & 0.005 & 0.003 & - \\
\hline
\end{tabular}

（注）セファデックス G-200により分離

Leu-2-NNap : Leu-2-ナフチルアミド

Leu-p-NA : Leu-p-ニトロアニリト

第 6 表 榃菌の酸性カルボキシペプチダーゼの組成 ${ }^{26)}$

\begin{tabular}{|c|c|c|c|c|}
\hline $\begin{array}{l}\text { 酸性カルボキシ } \\
\text { ベブーザ }\end{array}$ & 分子量 & $\begin{array}{c}\mathrm{Cbz}-\mathrm{Glu-} \\
\text { Tyr } \\
\text { 単位/g 梖 }\end{array}$ & $\begin{array}{l}\mathrm{Cbz}-\mathrm{Ala}- \\
\text { Glu } \\
\text { 単位 } / \mathrm{g} \text { 数 }\end{array}$ & $\begin{array}{c}\text { 酧素 量 } \\
\mu \mathrm{g} / \mathrm{g} \text { 数 }\end{array}$ \\
\hline I & 120,000 & \multirow{2}{*}{\}$_{\text {(III が主体) }}^{0.18}$} & \multirow{2}{*}{\} (I が主体) } & 9.9 \\
\hline II & 105,000 & & & 18.9 \\
\hline III & 61,000 & 0.049 & 0.005 & 61.6 \\
\hline IV & 43,000 & 0.111 & 0.018 & 8.2 \\
\hline
\end{tabular}

（注）セファデックス G-100により分離

$\mathrm{Cbz}$ : カルボベンゾキシ

は枚挙にいとまないほどである。

そこで, 中台 ${ }^{26)}$ が, A. sojae の醬油䚅中のプロテアー ゼ系酵素をセファデックス G-100 または G-200 で分画 した結果を，第 4,5,6 表に示す。アルカリ，七ミアルカ リ各 1 種, 中性 2 種, 酸性 3 種のプロテアーゼがあり, 供試した醬油棅中のプロテアーゼ系酵素の含量は, プロ テアーゼが $0.132 \%$ ，ロイシンアミノペプチダーゼが $0.087 \%$, 酸性カルボキシペプチダーゼが $0.010 \%$, 乾物 楼菌菌体当りでは合計 $1.91 \%$ あ゙あるとを明らかにした。

醬油憗菌はアルカリプロテアーゼ活性が強いために, 実用的見地から，この酵素に関する研究が最も多い。林 $ら^{27 \sim 30)}$ は, A. sojae のアルカリプロテアーゼを電気泳動 的に均一な状態に精製し, その酵素化学的, 物理化学的 諸性質を明らかにした。すなわち，アルカリプロテアー ゼは，ほかの多くのセリンプロテアーゼと同様に，典型 的なエンドペプチダーゼであり，多くのタンパク質を加 水分解する。大豆タンパク質に対しては, そのペプチド
結合の 8〜11\%を切断し，平均 9〜12 残基のペプチド を生成する。遊離アミノ酸はほとんど生じない。ペプチ ド結合の切断点としては, カルボキシル基側のアミノ酸 残基に最大の特異性をもつ。換言すれば，チロシン・フ エニールアラニン・ロイシンなどの芳香族または踈水性 アミノ酸残基に特異性を有するほか, アルギニン・リシ ンなどの塩基性アミノ酸残基にも特異性がある。

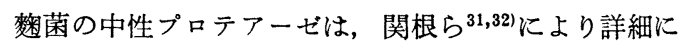
研究された。中性プロテアーゼIは, 種々のタンパク質 を分解し，とくにミルクカゼインや大豆タンパク質をよ く分解する。この事実は, 醬油醸造に拈いて, 中性プロ テアーゼIがアルカリプロテアーゼに劣らず重要な役割 を果していることを示す。一方, 中性プロテアーゼII は, 大豆タンパク質の分解性は低く，プロタミンやヒス タミンのような塩基性タンパク質によく働く。中性プロ テアーゼもエンドペプチダーゼであり，遊離アミ，酸は ほとんど生成しない。

田上ら ${ }^{331}$ は, 109 株の猌菌のプロテアーゼ組成を検討 し, 中性プロテアーゼ活性の割合は, 総プロテアーゼ活 性の 10〜20\% に集中しており, 総プロテアーゼ・中性 プロテアーゼの両活性の強い菌株は見出せなかったと報 告した。さらに大豆タンパク質に対する溶解性は, 総プ ロテアーゼ活性が同じなら, 中性プロテアーゼ割合の高 い菌株のほうが優れていることを認めた。

A. sojae や A. oryzae の酸性プロテアーゼも, 䄽油醸 造における原料タンパク質の分解に無視できない役割を

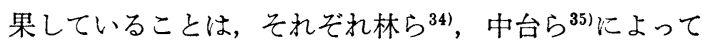
明らかにされた。また辻田ら ${ }^{36)}$ は，A. oryzae の酸性プ ロテアーゼが細胞壁の表面に局在することを推定した。

山本 ${ }^{37)}$ は, 稞菌プロテアーゼの生産条件としては, 培 地の水分・ $C / N$ 率・ $\mathrm{pH}$, 培養時間のほか, とくに培養 温度が重要であることを提示した。それによると, 高温 では麴菌の生育がよく, プロテアーゼ生産は立上りは早 いけれども，終局的には低くなり，むしろ $20 \sim 25^{\circ} \mathrm{C}$ の 低温で培養することにより, 酵素生産量が顕著に多くな るといら実用上重要な知見がえられた。従って実際に は, 麴菌菌系がある程度伸びるまでは比較的高温 30〜 $35^{\circ} \mathrm{C}$ に保ち, その後のプロテアーゼ生産期間では 20〜 $25^{\circ} \mathrm{C}$ の低温で製楼するほうが，酵素活性の高い棅の製 造に適することが判明した。

1.2.3 ペプチダーゼ 森菌ペプチダーゼの精製 と 性質については, 佐藤ら ${ }^{38,39)}$, 一島 $5^{40)}$, 小沢 $5^{41)}$ の研 究がある。中台ら ${ }^{26}$ によると, 䒇油麳菌は, 第 5,6 表の ような多種類のペプチダーゼを生産する。これらは, ペ プチドのアミノ末端から水解するアミノペプチダーゼ と, カルボキシ末端から分解する酸性カルボキシペプチ 
ダーゼに大別できる。

中台ら ${ }^{42)}$ は, A. oryzae 亡A. sojae の生産する各種の プロテアーゼ系酵素として，アルカリプロテアーゼと中 性プロテアーゼ I·II, アミノペプチダーゼ 3 種, 酸性カ ルボキシペプチダーゼ 4 種を分離・精製し, $\mathrm{L}_{16}\left(2^{15}\right)$ 型 直交配列法を用いた推計学的解析によって, これらの酵 素が大豆タンパク質の分解において演ずる役割を検討し た。その結果, 醬油醸造中に和けるフォルモール態窒素 (主にアミノ酸とアンモニア), グルタミン酸の生成に は, ペプチダーゼとくにロイシンアミノペプチダーゼII の寄与率が大きいことが明らかになった。この知見は, 醬油の呈味の主体をなすアミノ酸の生成に関与する䴿菌 ペプチダーゼの役割を明確にした点で, 意義が極めて大 きい。

1.2.4 グルタミナーゼ 醬油原料中のタンパク質 には, 相当量のグルタミン酸がグルタミン態として含有 されている。原料の加水分解に伴って遊離されてくるグ ルタミンは, 低 $\mathrm{pH}$ や高温の条件下では, 無味なピログ ルタミン酸に変撸されやすい。そこで, 諸味中で生成し たグルタミンを直ちに脱アミドして，グルタミン酸にす るグルタミナーゼの著量生産能も楼菌に要求される。加

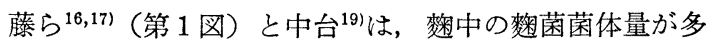
いほど醬油中のグルタミン酸が増加し，また䊬菌グルタ ミナーゼは大部分が不溶性で, 慗菌菌体に結合した形で 存在することを示した。

四方ら ${ }^{43)}$ は, 一連の詳細な研究によって, 稞菌グルタ ミナーゼには, 不溶性と可溶性のものが存在することを 認めた。両酵素の至適 $\mathrm{pH}$ には差がない。しかし棅菌菌 体に結合した不溶性グルタミナーゼは, $\mathrm{pH}$ 安定性・耐 塩性が優れ, 食塩阻害も小さく, かつ出猌中では量的に も多い。さらに第 2 図のように, この不溶性グルタミナ 一ゼあるいは全グルタミナーゼの量と, 枆の消化物や熟 成後の諸味中のグルタミン酸量との間には, 高い正相関 があることを明らかにした。

1.2 .5 植物組織崩壊酵素, その他の酵素醬油原 料の細胞壁や細胞間には, グルカン・ペクチン・ヘミセ ルロースなどが含まれている。石井ら ${ }^{44)}$ は, これらを分 解する植物組織崩壊酵素 $\beta$-グルカナーゼ系, ペクチナ 一ゼ系, ヘミセルラーゼ系の強いA. sojae No. 48 を選 択した。この菌株を用いて醬油醸造を行うと, 総窒素溶 解利用率や糖分解率が向上し, 諸味粘度も低下してろ過 速度が大きくなり，圧搾後の粕量の減少などを認めた。 ペクチンリアーゼとくにペクチントランスエリミナーゼ が高濃度食塩で阻害されるので, 醬油醸造では, へミセ ルラーゼとともにペクチナーゼが重要な酵素であると推 定している。



第 2 図麴菌の不溶性グル タミナーゼと諸味中グル タミン酸との関係 ${ }^{43)}$ **: $1 \%$ の危険貉で有意
また山本ら ${ }^{451}$ は, 市 販種稞菌のキシラナー ゼ活性と中性・アルカ リプロテアーゼ活性と の間に高度の有意の相 関を認め, 醬油醸造な どにおけるへミセルロ ースとタンパク質の分 解に関連性のあること を示した。

醬油醸造において必 要な䊝菌酵素は前述の ものに限らない。 $\alpha$-ア ミラーゼやグルコアミ

ラーゼも多少は必要である。GOEL ら ${ }^{46)}$ は, A. oryzae の

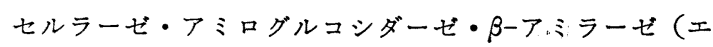
キソアミラーゼ) 等は, プロテアーゼと同様に重要な酵 素であると述べている。

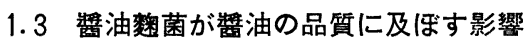

䅗菌が醬油の品質に影響を及ぼすのは，主として，そ の生産するプロテアーゼ系酵素とグルタミナーゼの作用 によって，グルタミン酸はじめ呈味の強いアミノ酸を生 成することを介してである。麴菌の酵素組成やその生産 能, 従って諸味中に打るアミノ酸生成能は菌株ごとに 異なる。そこで実際の醬油䁔造では, これらの酵素組成 のバランスがよく，しかも酵素生産能の高い菌株の使用 が望ましい。

従来, 醇造の過程で起こる微生物の自己消化は, 呈味 成分の生成に重要な役割を果していると漠然と考えられ ていた。魚住 ${ }^{47)}$ は, 蕃菌の自己消化機構を詳細に研究し た。ヌクレアーゼインヒビターで抑制されているヌクレ アーゼOが活性化されると，椈菌菌体内の核酸の $90 \%$ が分解され，つぎに菌体内タンパク質の $75 \%$ ，糖分の $20 \%$ が分解・溶出されることを明確にした。そして自 己消化産物は, 核酸からはウリジン・キサンチン・ヒポ キサンチンなどの塩基類が, タンパク質からはアミノ 酸・ペプチドが, 糖分からは平均重合度 1.1 1 1.4 の糖 とグルコース・リボース・グルコサミンなどが検出され た。しかし特別な呈味成分は見出されなかった。

また製椈過程で䴹菌の生育に伴って，後述のように小 麦のリグニン・配糖体からフェノール系の香味成分の前 駆体がつくられる ${ }^{48)}$ 。麥菌は, 製䊍中に, 醬油醸造にと って必要な種々の酵素を生産する以外に, 諸味中で活動 する乳酸菌や酵母の生育因子としてのビタミン類や他の 物質を生成する ${ }^{49)}$ 。㹼は, 耐塩性酵母の要求するパント テン酸・イノシトール・ビオチン・チアミン・耐塩性乳 
酸菌の要求するビオチン・パントテン酸・ニコチン酸・ ピリドキシン・ピリドキサール・リボフラビンなどの豊 富なビタミン類の給源となっている。

そのほか麴の $\mathrm{pH}$ や残糖量は, 仕込後の諸味中で生育 する乳酸菌・酵母の生育や発酵にも大きな影響を及注 す。加えて, 醬油の含有する約 $1 \%$ のグルセロール中の 約半分は，製整中に整菌によって生産されることも重要 な事実である。従って実用の椈菌体は, 酵素生産能以外 に，これらの諸点も加味して選択すべきである。

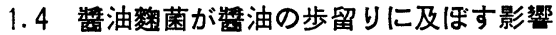

よく知られているように，プロテアーゼ系酵素の生産 能の高い楼菌株でつくった猌で仕込むと，原料中のタン パク質の溶解性がよく，いわゆる総窒素溶解利用率が高 くなり，醬油の歩留りが向上する。とくにアルカリプロ テアーゼと中性プロテアーゼI は大豆タンパク質の分解 性が優れているので25,32)，㛫菌の選択あるいは育種改良 では, 両プロテアーゼ生産能の高い菌株の取得が第 1 目 標となる。

歩留りに関与する酵素には, 他に植物組織崩壊酵素が ある。これはプロテアーゼと協同的に作用して窒素成分 の溶解性を高めるとともに, 諸味のろ過・圧搾性を向上 するので44,50)，醬油醸造では重要な酵素群である。最近， 中台ら ${ }^{511}$ は，醬油諸味の粘度とろ過性に関与する粘菌酵 素系を, 多数の麵菌株について段階的重回帰分析を用い て解析した。ろ過性に対して寄与率の大きな酵素は, ペ クチン液化酵素・ペクチンリアーゼ・ペクチン酸液化酵 素・CMC 糖化酵素であるとし，これらの酵素の意義を 明らかにした。

さらに醬油醸造において歩留りに影響するのは, 諸味 圧搾後に兄られる生醬油を加熱・殺菌する火入れ工程 で，火入れタンクの底に沈降する火入れ垽の多少であ る。プロテフーゼやアミラーゼなぞの麴菌酵素は, 諸味 熟成後にも相当量が残存している。この残存酵素が，火 入れ工程に扮いて，プロテアーゼ作用と熱変性により， 露出した疎水性に富むコアをつくり，つぎに疎水的相互 作用に上り凝集・会合して火入れ垽となる52)。火入れ蚚 の量は, 容量比で醬油の約 10\% 飞も達する。火入れ泝 が少なく，その凝集・沈降性のよいほうが，最終的に兄 られる醐油の歩留りが多くなり, また作業性も向上する ことになる。

\section{5 踾油数菌の選択・育種}

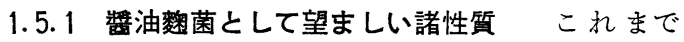
述べた䴴菌についての研究結果を総合して, 実際の醬油 醇造上の見地から麭菌の望ましい主な諸性質を列記する と，以下のようになると考觉られる。

1）原料タンパク質の溶解性向上のために，アルカリ
プロテァーゼ, 中性プロテアーゼ（とくにI）の生産能 が高いこと

2）原料タンパク質のアミノ酸化率，グルタミン酸生 成能の向上のために，ロイシンアミノペプチダーゼ（と くにII)やグルタミナーゼの生産能が高いこと

3）諸味のろ過・圧㩁性の向上のために，ペクチンリ アーゼのような植物組織崩壊酵素の生産能が高いこと

4）火入れ泝母体を少なくし，火入れ垽の凝集性を高 めるために，それぞれ適量のアミラーゼと酸性プロテフ 一ゼを生産すること

5）諸味微生物の発醉基質を多くするために，製蔔中 の糖消費量があまり多くない菌株であること

6）製赖中に生産されるビタミン類，香味成分，その 前駆物質などが十分であり，さらに䴶菌自己消化液の香 味が悪くないこと

当然，これらの諸性質がすべて優れた麴菌株を選択す ることは相当の困難を伴う。そこで変異や細胞融合によ って，㐫る麴菌株に不足する能力を強化したり，望まし くない性質を改変することが必要汭ことがある。

1.5.2 变異・選択実用的な秒菌株の育種改良の 際には，前記 6 項目の涂かにも，等閑に付しやすい次の ような多くの性質が兼備されることが必須であると考兄 られる。それは，(1)種椈の胞子着生が良好であること， (2)マイコトキシン生産能がないか，極めて低いこと，(3) 醬油の品質に大きな変化を与えないこと，(4)製䴴中の作 業性が劣らないこと, (5)変異株や細胞融合株の生育がよ く，かつ遺伝的に安定性の高いことなどが，全部満足さ れなければならない。

つとに井口 ${ }^{53,541}$ は，親株 A. soiae KS にX線を照射し て, プロテアーゼ系酵素の生産能が親株の約 2 倍強い変 異株 X-816 を造成した。その後, 那須野ら ${ }^{55 \sim 581}$ は, こ の变異株に紫外線照射や薬剂処理などの変異手段を施し て, さらにプロテアーゼ系酵素の強力な変異株を造成し た。これは, 酵素生産の調節機構に変異が起きた結果, 酵素生産量が数倍に向上したもので，酵素化学的性質は 親株と同じであった。またグルタミン酸生成に寄与率 の高いアミノペプチダーゼが，親株 A. oryzae 460 上 り約 2 倍高い变異株も，紫外線照射によって造成され $た^{59,60)}$ 。

プロテアーゼ以外の酵素については, 山本ら ${ }^{611}$ 结, 紫 外線照射によりグルタミナーゼ生産能の高いA. sojae No. 262 といら变異株を造成した。この变異株を用いて 小規模で醬油を醸造して, 諸味液汁中の遊離グルタミン 酸が増加することも確認した。このように変異による数 菌の育種は, 少数の性質や 2,3 の醉素の生産能を改良寸 るときに有効である。 
第 7 表 融合緑色株の性質 ${ }^{67)}$

\begin{tabular}{|c|c|c|c|}
\hline 菌 No. & 生 $(\mathrm{mm}){ }^{\text {育 }}$ & $\begin{array}{l}\text { プロテアーゼ } \\
\text { (x102unit/g) }\end{array}$ & $\begin{array}{c}\text { 槒中菌体量 } \\
(\%)\end{array}$ \\
\hline g 201 & 76.1 & 9.68 & 24.9 \\
\hline g 344 & 76.9 & 9.85 & 25.0 \\
\hline No. 8536 & 49.5 & 33. 38 & 13.8 \\
\hline No. 13 & 78.5 & 4. 30 & 25.9 \\
\hline
\end{tabular}

しかし場合によっては，自然界から優れた菌株を選択

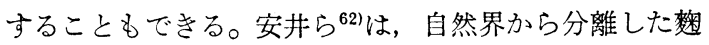
菌を親株として単胞子分離を行い,グルタミナーゼ生産 能が約 $28 \%$ 高い菌株をえた。この菌株で造った醬油 は,グルタミン酸が約 $10 \%$ も增加したことを報告し た。さらに四方ら ${ }^{631}$ は，醬油中のグルタミン酸を多くす る興味ある菌株を自然界から分離している。この菌株 は，これまでの知見と異なり，グルタミナーゼの生産能 は低いけれぞも，予想外に醬油中のグルタミン酸を増加 させるといら興味ある性質をるっていた。その原因は， この菌株は，慗䔩中に抢ける原料中グルタミン酸の消費 が少なく，原料中の残存グルタミン酸が多いためであっ た。

1.5.3 プロトプラスト融合＼cjkstart秒菌の他の育種改良 法としては, 種内あるいは種間の 2 つの菌株から, 新種 の体細胞種を造成する細胞融合法がある。

小田ら ${ }^{64,65)}$ は, A. sojae の高プロテアーゼ生産株 X816 とその親株 KS との交雑によって, ヘテロカリオン を経て 2 倍体を党た。これらは，プロテアーゼやアミラ 一ゼの生産量は両親株の中間の性質を示し, 酵素の性質 は両親株と同じであったことを認めた。

細胞融合を効率よく行うためには，まず，それぞれの 宷菌から細胞壁を除去したプロトプラストを調製する必 要がある。能美ら ${ }^{661}$ は，カタッムり醉素を利用して， $A$. oryzae のプロトプラストの効率的な調製法を考案した。 さらに麴菌プロトプラストからの菌系の再生には，2つ

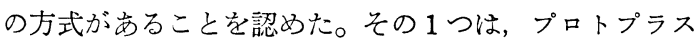
トから直接，発芽管様の菌系を伸長する方式である。他 はプロトプラストが酵母状に連絡し，その末端の細胞か ら菌系を伸ばす方式である。

古屋ら ${ }^{67}$ 法，上記の方法を用いて A. oryzae のプロト プラストをつくり，実際に優れた性質をもつ細胞融合株 を光た。すなわち第7表のように，プロテアーゼ活性が 弱くて生育速度の大きい親株 (No.13) と，プロテアー ゼ活性が強力で生育速度の小さい变異株 (No. 8536) と の種内で, プロトプラスト融合を行なわせた。兄られた ヘテロカリオンに紫外線照射して, 安定な 2 倍体（g 201，g 344）を造成した。これらの 2 倍体は，生育速度 が親株に近く, プロテアーゼ生産能は両菌株の中間値を

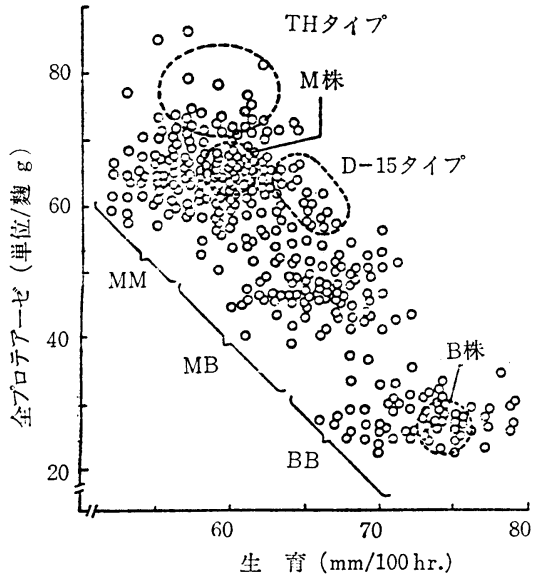

第 3 図 棦菌 2 倍体の生育と全プロテアーゼ活 性の分布 ${ }^{68)}$

示し，実用性の高い新しい菌株であることを認めた。

また横山ら ${ }^{681}$ は, A. sojae $\mathrm{H}$ に紫外線照射して, 生育 は親株より劣るけれどもアルカリプロテアーゼ生産能の 高い变異株（M）をえた。つぎに第 3 図のように，吻合 法により, M株の変異株同志の 2 倍体 (MM) でプロテ アーゼがM株より高いもの，およびM株とB株（M株の 自然変異株) のへテロ 2 倍体 (D-15 タイプ) などで生 育のよい優れた菌株を造成した。さらに 2 倍体 D-15 株 の紫外線照射によって, 生育が良好で, かつM株の 1.3 〜1.5 倍のプロテアーゼ生産能をもつ菌株を高頻度で兄 ている。

牛島ら ${ }^{69)}$ も, Bacillus circulans の細胞壁融解酵素之市 販キチナーゼとの併用で, A. sojae のプロトプラストを 調製し，その融合によって高プロテアーゼ生産菌株と高 グルタミナーゼ生産菌株との中間の酵素生産能をるつ 2 倍体を造成した。つづいて牛島ら 外線を照射すると, プロテアーゼ・グルタミナーゼの生 産量が向上し，各親株の $75 \%$ に達することを認めた。 また 2 倍体を Benomyl で半数体化処理して, プロテア 一ゼが高プロテアーゼ株と同じで，グルタミナーゼが 2 倍高い菌株を造成した。

今後は，プロテアーゼ系酵素やグルタミナーゼの及に 限らず，醬油䁔造関与する他の酵素や生理的性質にも 範囲を広げた，細胞融合による醬油䴯菌の育種が必要に なるのではないかと考光られる。

(つづく)

くテッニーマン(株)醸造科学研究所〉

文献

1）中浜敏雄編：醬油醅造の最近の技術と研究 日本 醇造協会 (1972)

2）坂口謹一郎, 山田浩一: 農化 2065 141(1944)

3) H. Murakami : J.Gen. Appl. Microbiol. 17281 
(1971)

4）村上英也：醸試報 1435 (1971), 調味科学 20 (9) 2 (1973)

5）村上英也：発協誌３0193(1972)，食衛誌 131 (1972)

6）村上英也：醇協 66 (2) 117, （7）658,（8）759, (9) 859, (10)966, (11) 1042 , (12) 1150 (1971), 68(4) 305 (1973)

7）村上英也：醇協 77(3) 152 (1982)

8) H. Murakami, K. Hayashi, S. Ushijima : $J$. Gen. Appl. Microbiol. 2855 (1982)

9) K. Yuasa, K. Hayashi : Agric. Biol.Chem. 46 1683 (1982)

10）那須野精一: J. Gen. Microbiol. 7129 (1972), Can.J. Microbiol. 20413 (1974), 調味科学 21 (7) 2 (1974)

11）寺田 勝, 林 和也, 水沼武二 : 醬研 6 75(1980), 7 158(1981)

12）林 和也, 寺田 勝, 水沼武二 : 醬研 7166 (1981)

13）佐々木正興，横塚 保：発協誌 30205 (1972)

14）倉田 浩: 微生物の生態 9, 糸状細胞 p.96 微生 物生態研究会編（学会出版センター）(1981)

15）奈良原英樹：醱工 55254 (1977)

16）加藤 威, 小林邦男, 泉 保広, 花岡嘉夫 : 農化 50395 (1976)

17) 加藤 威 : 醬研 3178 (1977)

18）小崎道雄, 北原覚雄 : 日食工誌 2138 (1974)

19）中台忠信 : 醬研 774 (1981)

20）高草 仁, 伊達真一郎, 石山有造, 奥野敏男, 森 口繁弘：調味科学 19(10) 21 (1972)

21) T. Mizunuma : Agric. Biol. Chem. 2788 (1963)

22）好井久雄: 醹協 59 (5) 406, (6) 489,（7)604, (8) 701 , (9) 783, (10)886 (1964)

23）一島英治：醸協 67(11) 928 (1972)

24）森原和之：醇協 70(9) 632（1975）

25）井口信義, 那須野精一：醇工 56645 (1978)

26）中台忠信 : 醬研 399 (1977)

27）林和也, 福島男児, 茂木孝也：調味科学 17 161 (1970)

28）林 和也, 寺田 勝, 福島男児, 茂木孝也 : 調味 科学 17170 (1970), 18281 (1971)

29）林 和也, 寺田 勝, 茂木孝也: 調味科学 17187 (1970)

30）林 和也：発協誌 30325 (1972), 化学と生物 1182 (1973)

31) H. Sekine, S. Nasuno, N. Iguchi : Agric. Biol. Chem. 341690 (1970)

32) H. Senine : Agric. Biol. Chem. 40703 (1976)

33）田上秀男, 菅原周一：醬研 3111 (1977)

34）林 和也, 水沼武二 : 農化大会講演要旨集 p. 42 (1974)

35) T. Nakadal, S. Nasuno : Agric. Biol. Chem. 41409 (1977)

36) Y. Tsujita, A. Endo: $J$. Biochem. 88113 (1980)

37) K. Үамамото: Bull. Agric. Chem. Soc. Japan
21313,319 (1957)

38) M. Sato, T. Akntsuka : Bull. Agric. Chem. Soc. Japan 23465 (1959)

39) T. Akntsuka, M. Sato:Bull. Agric. Chem. Soc. Japan 2771828 (1963)

40) E. Ichishima, S. Sonoki, K. Hirai, Y. Torit, S. Yokoyama: J. Biochem. 721045 (1972)

41) Y. Ozawa, K. Suzuki, T. Mizunuma, K. Mogi : Agric. Biol.Chem. 371285 (1973)

42) T. Nakadai, S. Nasuno, N. Iguchi : Agric. Biol.Chem. 362611239 (1972)

43）四方日出男 研 448 (1978), 521 (1979)

44）石井茂孝, 菊地忠昭, 大上忠男, 横塚 保：農化 46349 (1972)

45）山本 泰, 東 和男, 好井久雄: 日食工誌 28 496 (1981)

46) S. K. Goes, B. J. B. Wood : J. Food Technol. 13243 (1978)

47） 魚住武司：農化 51 R75（1977）

48）横塚 保，佐々木正興，布村伸武浅唓保夫：醸 協 75 (6) $516 ，(9) 717$ (1980)

49）好井久雄 : 醸協 66(2)111 (1971)

50）菊地忠昭：醬研 571 (1979)

51）中台忠信，相島鉄郎：農化 57307 (1983)

52）橋本彦堯：醊工 55294 (1977)

53）井口信義：農化 2973 (1955), 醱工 34553 (1956)

54）井口信義, 山本喜志郎：農化 29387394 (1955)

55) S. Nasuno, T. Ohara, N. Iguchi : Agric. Biol. Chem. 35291 (1971)

56) S. Nasuno, T. Ohara : Agric. Biol. Chem. 35 829836 (1971)

57）那須野精一, 小原忠彦, 井口信義 : 調味科学 19 (10) 27 (1972)

58）那須野精一, 小原忠彦：調味科学 19(10)41(1972)

59) S. Nasuno, T. NAKadaI : J.Ferment. Technol. 49544 (1971)

60) T. Nakadai, S. Nasuno : J. Ferment. Technol. 55273 (1977)

61) S. Үамамото, H. Hirooka : J.Ferment. Technol. 52564 (1974)

62）安井卓男, 四方日出男, 石山有造 : 醬研 8117 (1982)

63）四方日出男, 安井卓男, 石山有造, 石川 浩 : 醬 研 959 (1983)

64) K. Oda, N. Iguchi : Agric. Biol.Chem. 27758 (1963)

65) K. ODA : Agric. Biol.Chem. 27767 (1963)

66）能美健彦, 一島英治：醸協 78(3) 167 (1983)

67）古屋 武, 石毛雅夫, 内田一生, 吉野 宏: 農化 575 (1983)

68）横山 勉, 門脇 清 : 醬研 9137 (1983)

69）牛島重臣，中台忠信：醱工大学講演要旨集 p. 260 (1983)

70）牛島重至，中台忠信：農化大会講演要旨集 p. 83 (1984) 